\title{
融液の一方向凝固により得ら水る $\mathrm{Li}_{2} \mathrm{O} \cdot 2 \mathrm{SiO}_{2}$ 多結晶体の 微細構造に対する第 3 成分添加の影響
}

(1978 年 4 月 8 日受理)

有阔雅行・小久保正・田代 仁*

$\mathrm{Li}_{2} \mathrm{O} \cdot 2 \mathrm{SiO}_{2}$ 組成抢よび, この組成 $100 \mathrm{~mol}$ 飞対し, $3 \mathrm{~mol}$ の $\mathrm{B}_{2} \mathrm{O}_{3}, \mathrm{Na}_{2} \mathrm{O}, \mathrm{MgO}, \mathrm{Al}_{2} \mathrm{O}_{3}, \mathrm{SiO}_{2}$ ある いは $\mathrm{P}_{2} \mathrm{O}_{5}$ を添加した組成の融液を, 底に $\mathrm{Li}_{2} \mathrm{O} \cdot 2 \mathrm{SiO}$ ガラスセラミック薄層を種子結晶として形成 させておいた粘土ルッボ中で下部から上方に向け $1.3 \mathrm{~mm} / \mathrm{hr}$ の速度で疑固させた。得られた凝固物は いずれも，ルッボ底面に垂直に伸びた $\mathrm{Li}_{2} \mathrm{O} .2 \mathrm{SiO}_{2}$ 柱状晶からなり，その伸長方向は同結晶の $c$ 軸に 一致していた。凝固物の柱状晶の平均径は $\mathrm{Li}_{2} \mathrm{O} \cdot 2 \mathrm{SiO}_{2}$ 組成の場合に $560 \mu \mathrm{m}$ であるのに対し, 添加 物を含む場合は，いずれもこれより小さく 170 440 $\mu \mathrm{m}$ であった。凝固物の真気孔率は $\mathrm{Li}_{2} \mathrm{O} \cdot 2 \mathrm{SiO}_{2}$ 組成の場合に 3.4\% であるのに対し， $\mathrm{Na}_{2} \mathrm{O}$ および $\mathrm{B}_{2} \mathrm{O}_{3}$ を添加した場合には，それぞれ 1.1 およ び 1.7\% で小さく， $\mathrm{Al}_{2} \mathrm{O}_{3}$ および $\mathrm{P}_{2} \mathrm{O}_{5}$ を添加した場合には，それぞれ 9.1 および 7.6\%で大きか った。 $\mathrm{Na}_{2} \mathrm{O}$ 牰よび $\mathrm{B}_{2} \mathrm{O}_{3}$ を添加した場合に，凝固物の真気孔率が減少したおるな原因は，柱状晶間に 5〜7 wt\% のガラス相が形成され，このガラス相が柱状結晶析出後の冷却時に流動することによって結 晶中に生じる熱応力を緩和し，結晶粒間に亀裂が発生するのを抑制するためと考えられる。

\section{1 緒霄}

著者らは，粘度の高い一致溶融組成の融液から，一方向凝固法 Kより維密な配向性多結晶体を製造する基礎的条件を明らかにす る目的で，さきに $\mathrm{Li}_{2} \mathrm{O} \cdot 2 \mathrm{SiO}_{2}$ 組成の融液の凝固条件と凝固物の 結晶の配向性，粒径および気孔率の関係を調べ，つぎの結果を得 た1)2)。すなわち粘土ルシがの底の内面にあらかじめ薄い $\mathrm{Li}_{2} \mathrm{O}$. $\mathrm{SiO}_{2}$ ガラスセラミック層を形成させて拉き，そのルシボ中で $\mathrm{Li}_{2} \mathrm{O} \cdot 2 \mathrm{SiO}_{2}$ 融液を下部から上方へ一方向に凝固させると，ルッ 校面に垂直に伸長した多数の $\mathrm{Li}_{2} \mathrm{O} .2 \mathrm{SiO}_{2}$ 柱状晶からなる凝固 物が得られる。この柱状晶の伸長方向は同結晶の $c$ 軸方向に一致 する。その柱状晶の径佉凝固速度が $13 \mathrm{~mm} / \mathrm{hr}$ から $0.7 \mathrm{~mm} / \mathrm{hr}$ に減少するにしたがい，340 $\mu \mathrm{m}$ から $580 \mu \mathrm{m}$ へ增加する。凝固 物の気孔率は，凝固速度が $13 \mathrm{~mm} / \mathrm{hr}$ から $1.3 \mathrm{~mm} / \mathrm{hr}$ 減少 するにしたがい減少し, $1.3 \mathrm{~mm} / \mathrm{hr}$ 以下の凝固速度の場合には， 約 $3 \%$ の一定の値を示す。

本研究は, $\mathrm{Li}_{2} \mathrm{O} .2 \mathrm{SiO}_{2}$ 組成 $100 \mathrm{~mol}$ に対し $3 \mathrm{~mol}$ の $\mathrm{B}_{2} \mathrm{O}_{3}$, $\mathrm{Na}_{2} \mathrm{O}, \mathrm{MgO}, \mathrm{Al}_{2} \mathrm{O}_{3}, \mathrm{SiO}_{2}$ あるいは $\mathrm{P}_{2} \mathrm{O}_{5}$ (以下これらの添加成分 を, $\mathrm{SiO}_{2}$ を含めて第 3 成分と記す）を添加した組成の触液を既 報”）同様の方法で一方向凝固させ，得られた凝固物の微細構造 を，第 3 成分を含まない㠜固物のそれと比较することにより，凝 固物の微細構造に対する第 3 成分添加の影響を明らかにすること を目的とする。

* 京都大学化学研究所, 611 宇治市五ヶ庄

1）有岡雅行，小久保 正，田代 仁，晕協，85，501(1977).

2) 有岡雅行, 小久保 正, 田代 仁, 羔協, 86, 368(1978).

\section{2 实験および結果}

\section{1 融液の疑固}

表 1 亿示す $\mathrm{Li}_{2} \mathrm{O} .2 \mathrm{SiO}_{2}$ 組成括よびこの組成 $100 \mathrm{~mol}$ に対し $3 \mathrm{~mol}$ の $\mathrm{B}_{2} \mathrm{O}_{3}, \mathrm{Na}_{2} \mathrm{O}, \mathrm{MgO}, \mathrm{Al}_{2} \mathrm{O}_{3}, \mathrm{SiO}_{2}$ あるいは $\mathrm{P}_{2} \mathrm{O}_{5}$ を添加し た組成のパッ約 $160 \mathrm{~g}$ を化学薬品の $\mathrm{Li}_{2} \mathrm{CO}_{3}, \mathrm{SiO}_{2}, \mathrm{~B}_{2} \mathrm{O}_{3}, \mathrm{Na}_{2}$. $\mathrm{CO}_{3}, \mathrm{MgO}, \mathrm{Al}_{2} \mathrm{O}_{3}$ および $\mathrm{P}_{2} \mathrm{O}_{5}$ を用いて調製し，それを $50 \mathrm{ml}$ の Pt $10 \% \mathrm{Rh}$ ルシボにスれ， $1400^{\circ} \mathrm{C} て ゙ 6$ 時間溶融した。溶融中 融液を石英オ゙ラス棒で 1 時間毎にかきま゙た。

一方，既報1) と同様に図 1 の SiC 発熱体電気姖中で粘士ルッボ （内径 $45 \mathrm{~mm}$, 媣さ $55 \mathrm{~mm}$ ) をその上部（上端より $35 \mathrm{~mm}$ 上

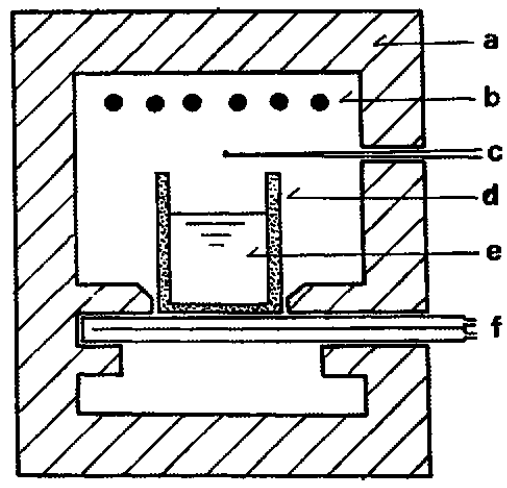

Fig.1 Schematic representation of the temperaturegradient furnace used for unidirectional solidification of melts

a : Refractory, b : SiC-heating elements, c: Thermocouple, d: Clay crucible, e: Melt, f: Water-cooled copper jacket 
Table 1 Composition and microstructures of ingots

\begin{tabular}{lllccc} 
Specimen & \multicolumn{1}{c}{$\begin{array}{c}\text { Composition } \\
\text { (in mole) }\end{array}$} & $\begin{array}{c}\text { Crystal } \\
\text { phase }\end{array}$ & $\begin{array}{c}\text { Glass content } \\
\text { (wt\%) }\end{array}$ & $\begin{array}{c}\text { Diameter of } \\
\text { crystal }(\mu \mathrm{m})\end{array}$ & $\begin{array}{c}\text { Total } \\
\text { porosity }(\%)\end{array}$ \\
\hline L 2S & $\mathrm{Li}_{2} \mathrm{O} \cdot 2 \mathrm{SiO}_{2}$ & $\mathrm{~L}$ & 2 & 580 & 3.4 \\
$\mathrm{~L} 2 \mathrm{~S}-\mathrm{B}$ & $\mathrm{Li}_{2} \mathrm{O} \cdot 2 \mathrm{SiO}_{2}+0.03 \mathrm{~B}_{2} \mathrm{O}_{3}$ & $\mathrm{~L}, \mathrm{Q}, \mathrm{C}$ & 5 & 170 & 1.7 \\
$\mathrm{~L} 2 \mathrm{~S}-\mathrm{Na}$ & $\mathrm{Li}_{2} \mathrm{O} \cdot 2 \mathrm{SiO}_{2}+0.03 \mathrm{Na}_{2} \mathrm{O}$ & $\mathrm{L}, \mathrm{Q}$ & 7 & 240 & 1.1 \\
$\mathrm{~L} 2 \mathrm{~S}-\mathrm{Mg}$ & $\mathrm{Li}_{2} \mathrm{O} \cdot 2 \mathrm{SiO}_{2}+0.03 \mathrm{MgO}_{2} \mathrm{~L}, \mathrm{C}, \mathrm{F}$ & 3 & 210 & 3.2 \\
$\mathrm{~L} 2 \mathrm{~S}-\mathrm{Al}$ & $\mathrm{Li}_{2} \mathrm{O} \cdot 2 \mathrm{SiO}_{2}+0.03 \mathrm{Al}_{2} \mathrm{O}_{3}$ & $\mathrm{~L}, \mathrm{~S}, \mathrm{C}$ & 1 & 220 & 9.1 \\
L 2 S-Si & $\mathrm{Li}_{2} \mathrm{O} \cdot 2 \mathrm{SiO}_{2}+0.03 \mathrm{SiO}_{2}$ & $\mathrm{~L}, \mathrm{C}$ & 4 & 410 & 2.7 \\
L 2S-P & $\mathrm{Li}_{2} \mathrm{O} \cdot 2 \mathrm{SiO}_{2}+0.03 \mathrm{P}_{2} \mathrm{O}_{5}$ & L, C, Q, P & 1 & 310 & 7.6
\end{tabular}

a) $\mathrm{L}: \mathrm{Li}_{2} \mathrm{O} \cdot 2 \mathrm{SiO}_{2}$ crystal, $\mathrm{Q}: \alpha$-Quartz, $\mathrm{C}: \alpha$-Cristobalite, $\mathrm{F}:$ Forsterite, $\mathrm{S}: \beta$-Spodumene, $\mathrm{P}: \mathrm{Li}_{3} \mathrm{PO}_{4}$ crystal.

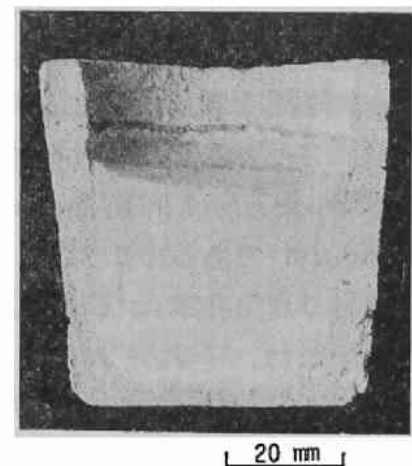

Fig. 2 Longitudinal section of a $\mathrm{L} 2 \mathrm{~S}-\mathrm{Na}$ ingot solidified at a rate of $1.3 \mathrm{~mm} / \mathrm{hr}$

方の位置）を $1200^{\circ} \mathrm{C}$ に加熱し，底部を水冷板により椧却して特 き, この粘土ルッボ中に上記の融液を注入した。粘土ルッポの底 には, 配向性のよい多結晶体を得るために, あらかしめ $\mathrm{Li}_{2} \mathrm{O} \cdot 2$ $\mathrm{SiO}_{2}$ ガラスセラミック薄層を形成させて抌いた1)。融液は注入後 ただちに底面から約 $10 \mathrm{~mm}$ の高さまで凝固し, その結果, 多数 の気泡が結晶面近くの融莅中に発生したので，この気泡をとり除 くため, 炉の温度をそのまま 10 時間たもった。その後ルシボ上 部の温度を $10^{\circ} \mathrm{C} / \mathrm{hr}$ の速度で降下させ, 底面から $10 \mathrm{~mm}$ 以上 の高さの融摔を下から上に向け，一方向に凝固させた。第 3 成分 を添加した組成の液相温度が $\mathrm{Li}_{2} \mathrm{O} \cdot 2 \mathrm{SiO}_{2}$ のそれに近いと仮定 し, 底から高さ $10 \mathrm{~mm}$ 以上の部分の融液の凝固速度を, 既報1) と同様にして, 冷却速度と融液の深さから算出すると, 凝固速度 は, いずれの組成の場合も $1.3 \mathrm{~mm} / \mathrm{hr}$ であった。

得られた凝固物のルシボ底面に垂直な切断面の一例を図 2 に示 す。図 2 は $\mathrm{Na}_{2} \mathrm{O}$ を含む㠜固物の切断面であるが, 他の凝固物 の切断面もほぼこれと同样であった。すなわち, 得られた凝固物 は，第 3 成分を含む場合も，含まない場合と同様，ルッボ底面に 垂直に伸長した多数の柱状晶からなっていた。

\section{2 析出結晶の種類およびガラス含有量}

凝固物中の析出結晶を同定するために，凝固物の底面から高さ 15 20 mm の部分から $3 \times 5 \times 5 \mathrm{~mm}$ の大きさの直方体を切り出 し，これを十分に粉碎して，粉末粒子の直径が $10 \mu \mathrm{m}$ 以下とな ったことを光学顥微鏡下で確かめたのち，X線回折分析を行なっ た。第 3 成分を添加しない凝固物, $\mathrm{Na}_{2} \mathrm{O}$ または $\mathrm{Al}_{2} \mathrm{O}_{3}$ を添加し た凝固物の粉末 $\mathrm{X}$ 線 ( $\mathrm{Cu} K_{\alpha}$ 線) 回折図を図 3 亿示す。他の凝固 物のX線回折図も小さいピークを除き，ほぼこれと同様であっ た。これらのX線回折分析の結果から凝固物は, 第 3 成分の有 無, その释類にかかわらず, いずれる大部分 $\mathrm{Li}_{2} \mathrm{O} \cdot 2 \mathrm{SiO}_{2}$ 結晶か

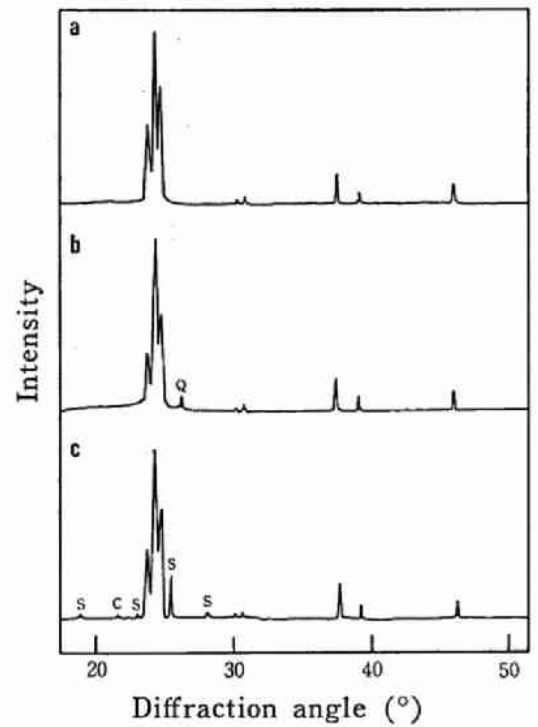

Fig. 3 Powdered X-ray diffraction patterns of (a) L 2 $\mathrm{S}$, (b ) L $2 \mathrm{~S}-\mathrm{Na}$ and (c) L $2 \mathrm{~S}-\mathrm{Al}$ ingots $\mathrm{Q}: \alpha$-Quartz, $\mathrm{C}: \alpha$-Cristobalite, $\mathrm{S}: \beta$-Spodumene, Others: $\mathrm{Li}_{2} \mathrm{O} \cdot \mathrm{SiO}_{2}$ crystal

らなることがわかった。第 3 成分を含む凝固物の場合には $\mathrm{Li}_{2} \mathrm{O}$. $2 \mathrm{SiO}_{2}$ 結晶の回折ピークのほが第 3 成分により異なる微少な $\mathrm{X}$ 線回折ピークが認められ，微量の $\alpha$-クリストパライト， $\alpha$-石 英，ホルステライト， $\beta$-スポジュメンあるいはりン酸リチウムの 結晶が析出していることがわかった。各凝固物中に検出された結 唱相を表 1 の第 3 欄比まとめて示す。いくつかの凝固物の回折図 上には回折角 $2 \theta=15 \sim 30^{\circ}$ にガラスによると考えられる幅広い X線のハローも認められた。図 3(b) とその一例を示す。

これらのハローの強度から, 各凝固物中のガラス含有量を求め る ${ }^{3)}$ ため, 上記の粉末試料について, 結晶による回折ピークの 認められない $2 \theta=19.6^{\circ}, 22.5^{\circ}$ 扰よび $27.6^{\circ}$ の各回折角度に拧 けるX線回折強度を, 試料を 5 回つめかえて, おのおの 100 秒間 シンチレーション計数管で計測した。これらを平均したX線強度 を, 所定量のガラスを含有する標準試料の同じ角度に拈けるX線 回折強度と比較することにより, 各角度ごとに粉末試料中のガラ ス含有量を求め, これを平均して各凝固物中のガラス含有量とし た。 $2 \theta=19.6^{\circ}$ 飞特ける検量線を図 4 亿示す。他の回折角度にお。 ける検量線もほとんどこれと同じであった。

3) S. M. Ohlberg, D. W. Strickler, J. Am.Ceram. Soc., 45, 170(1962). 


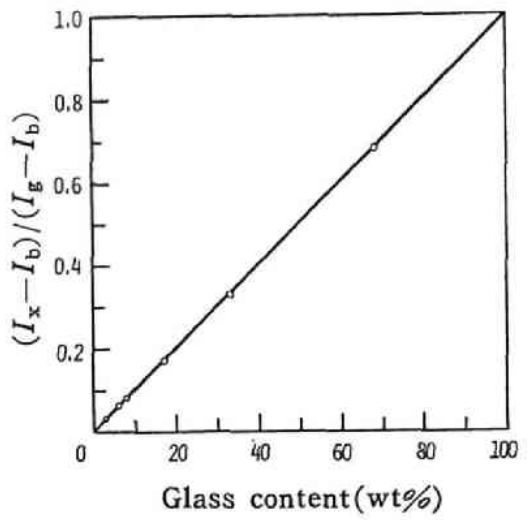

Fig.4 Relative intensity of $\mathrm{X}$-ray non-crystalline scattering $\left(I_{\mathrm{x}}-I_{\mathrm{b}}\right) /\left(I_{\mathrm{g}}-I_{\mathrm{b}}\right)$ measured at $2 \theta=19.6^{\circ}$ for a mechanical mixture of $\mathrm{Li}_{2} \mathrm{O} \cdot 2 \mathrm{SiO}_{2}$ glass and crystal vs. glass content

$I_{\mathrm{g}}, I_{\mathrm{b}}$ and $I_{\mathrm{x}}: \mathrm{X}$-ray scattering intensity of $\mathrm{Li}_{2} \mathrm{O} \cdot 2 \mathrm{SiO}_{2}$ glass, crystal and their mixture, respectively.

ガラス $100 \%$ 含有標準試料としては, $\mathrm{Li}_{2} \mathrm{O} .2 \mathrm{SiO}_{2}$ 融液を急 冷し, 粉砕して直径 $10 \mu \mathrm{m}$ 以下の粉末としたものを用い, ガラ ス $0 \%$ 含有標準試料としては，上記のガラス粉末を室温より 300 ${ }^{\circ} \mathrm{C} / \mathrm{hr}$ の速度で加熱し $460^{\circ} \mathrm{C} て ゙ 6$ 時間保持したのち, さらに同 し速度で, $930^{\circ} \mathrm{C}$ まて加熱し, そのまま 12 時間加熱して結晶化 させたものを用いた。 $460^{\circ} \mathrm{C}$ はガラス中の結晶核生成速度が最大 となる温度であり, また $930^{\circ} \mathrm{C}$ は結晶成長速度が最大となる温 度である4)5)。種々の量のガラスを含有する標準試料としては, 上 記の両試料を種々の重量比で混合したものを用いた。

このようにして求めた各凝固物中のガラス含有量を表 1 の第 4 櫊に示す。表 1 から第 3 成分を含まない凝固物中にも約 $2 \mathrm{wt} \%$ のガラスが含有されていること，および第 3 成分を含も凝固物の

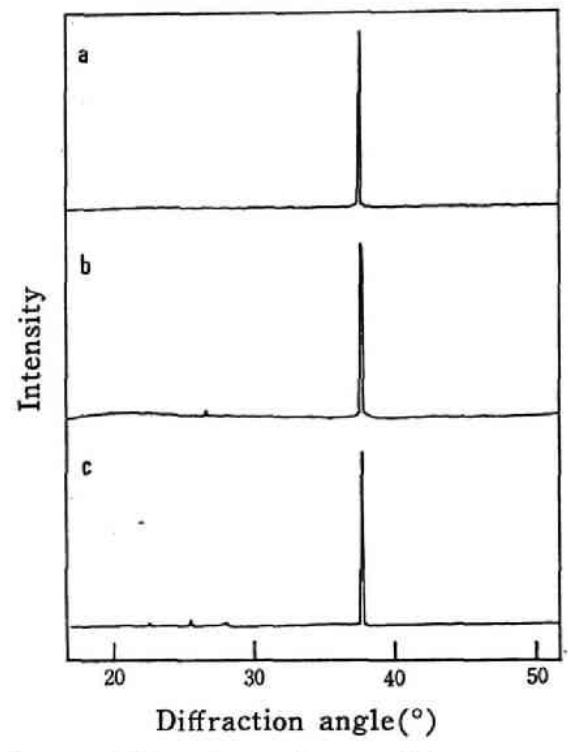

Fig. $5 \mathrm{X}$-ray diffraction patterns of transverse sections of (a) L $2 \mathrm{~S}$, (b ) L $2 \mathrm{~S}-\mathrm{Na}$ and (c) L $2 \mathrm{~S}-\mathrm{Al}$ ingots

場合には, 第 3 成分の種類により, ガラス量がかなり大きく变化 していることがわかる。すなわちガラス含有量は, 第 3 成分が $\mathrm{Al}_{2} \mathrm{O}_{3}$ 岕よび $\mathrm{P}_{2} \mathrm{O}_{5}$ の場合には, 1 wt \% またはそれ以下で少な いのに対し, $\mathrm{Na}_{2} \mathrm{O}$ および $\mathrm{B}_{2} \mathrm{O}_{3}$ の場合には 5〜7 wt\% と多く なる。

\section{3 結晶の配向性}

凝固物を底面から高さ $15 \mathrm{~mm}$ のところで底面に平行に切断し て, その切断面のX線回折分析を行なった。分析方法の詳細は既 報1)記したのと同じである。第 3 成分を含まない凝固物, $\mathrm{Na}_{2} \mathrm{O}$ を含む㠜固物および $\mathrm{Al}_{2} \mathrm{O}_{3}$ を含む凝固物のX線回折図を図 5 に

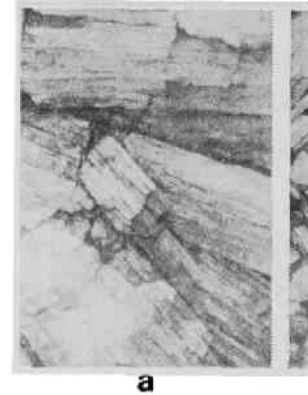

a

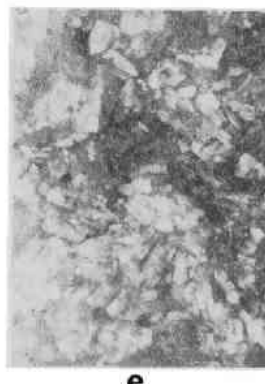

e

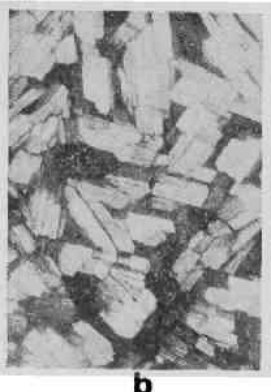

b

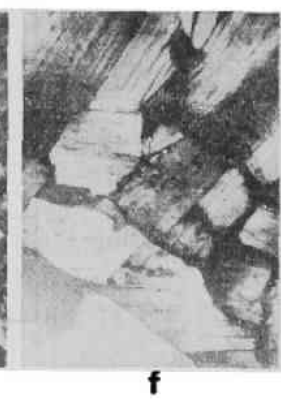

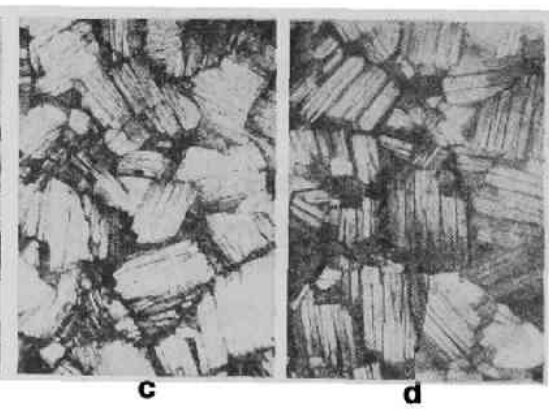

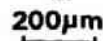

Fig. 6 Optical micrographs of transverse sections of (a) L $2 \mathrm{~S}$, (b) L $2 \mathrm{~S}-\mathrm{B}$, (c) L 2 S-Na, (d) L 2 S-Mg, (e ) L 2 S-Al, (f ) L 2 S-Si, (g) L 2 S-P ingots

4) K. Matusita, M. Tashiro, J. Non-Crystalline Solids, 11, 471(1973).
5) K. Matusita, M. Tashiro, Yogyo-Kyokai-Shi, 81, 60 (1973). 
示す。他の㠜固物のX線回折図も小さいピークを除き，汪ぼこれ と同様であった。図中，大きいピークは $\mathrm{Li}_{2} \mathrm{O} \cdot 2 \mathrm{SiO}_{2}$ 結晶の (001)面によるものであり，小さなピークは前節で記した $\mathrm{Li}_{2} \mathrm{O}$. $2 \mathrm{SiO}_{2}$ 以外の結晶によるものである。これらの結果から，いず れの㠜固物中でも $\mathrm{Li}_{2} \mathrm{O} .2 \mathrm{SiO}_{2}$ 結晶が，その $c$ 軸をほとんど完 全にルッポ底面に垂直にならべていることがわかる。

\section{4 結 晶 径}

得られた凝固物の底面から高さ約 $15 \mathrm{~mm}$ の部分から，底面に 平行に, 約 $2 \mathrm{~mm}$ 厚の板状試料を切り出しこれを研削して 0.5 $\mathrm{mm}$ 厚の薄片とし，偏光顕媺鏡下で観察した。それらの顕微鏡 写真を図 6 に示す。図 6 上の白い多角形は写真面に垂直に伸びた 角柱状結晶の断面であり，図 6(e) および(g) 上の黒い円は写真 面に垂直に伸びた円柱状気孔の断面である。それぞれの試料につ いて断面の顕微鏡写真を場所を変えて 5 枚撮影し，これらの写真 上で単位面積内に認められる柱状晶の数を測定し, 柱状晶の平均 直径を算出した。これを表 1 の第 5 欄に示す。第 3 成分を含まな い凝固物中の柱状晶の径は $560 \mu \mathrm{m}$ であるが，第 3 成分を含む 凝固物中の柱状晶の径は，それより小さく，170４40 $\mu \mathrm{m}$ であ る。

\section{5 気孔率}

凝固物の中でルッボの底から高さ $12 \sim 22 \mathrm{~mm}$ の部分から 10 $\times 10 \times 10 \mathrm{~mm}$ の大きさの試料を切り出し, Archimedes 法によ り,そのかさ比重を測定した。つぎにこの試料を粉砕し，200メッ シュのふるいを通過させたものについて，比重瓶法によりその真 比重を測定した。漫漬液としては，いずれの場合もトルェン（化 学薬品特級）を用い, その比重は上記試料の比重測定前後に浮き 秤比重計により測定した。これらのかさ比重および真比重から凝 固物の真気孔率を算出した。以上の測定は同じ試料についておの 将の 10 回行なった。表 1 の第 6 欄の数值はその平均値である。 表 1 から真気孔率は第 3 成分を含まない場合に $3.4 \%$ であるのに 対し， $\mathrm{Al}_{2} \mathrm{O}_{3}$ および $\mathrm{P}_{2} \mathrm{O}_{5}$ を含む場合にはそれより大きく，また $\mathrm{B}_{2} \mathrm{O}_{3}$ 打よび $\mathrm{Na}_{2} \mathrm{O}$ を含む場合はそれより小さいことがわかる。

図 7 は，第 3 成分を含まない L $2 \mathrm{~S}$ および $\mathrm{Na}_{2} \mathrm{O}$ を含む $\mathrm{L} 2$ $\mathrm{S}-\mathrm{Na}$ 凝固物のルッポの底から高さ $12 \sim 14 \mathrm{~mm}$ の部分からルッ ボ底面に平行に切り出した, 厚さ約 $3 \mathrm{~mm}$ の試料の写真である。 図 7 からこれらの試料の気孔率の美が試料の透明性にも反映し ていることがわかる。

\section{6 気孔の形および分布}

$\mathrm{Al}_{2} \mathrm{O}_{3}$ または $\mathrm{P}_{2} \mathrm{O}_{5}$ を添加した凝固物には円柱状気孔が存在す ることが図 6 の㩆微鏡写真から明らかである。しかし，その他の 凝固物の気孔の形および分布は同写真からは明らかでない。そこ でこれらをさらに詳しく調べるために，すべての凝固物につい て，その底面から上方 $15 \mathrm{~mm}$ の高さにおける底面に平行な切 断面を $\mathrm{CeO}$ 粉末で研磨したのち, $1 \% \mathrm{HF}$ 水溶液で 60 分間腐 食し，走查型電子影微鏡(日立-明石，MSM-2 型）下で観察した。 第 3 成分を含まない凝固物および $\mathrm{Na}_{2} \mathrm{O}$ を含む凝固物の電子鏡 薇鏡写真を図 8 に示す。 $\mathrm{B}_{2} \mathrm{O}_{3}$ または $\mathrm{Na}_{2} \mathrm{O}$ を含む凝固物中には, 亀裂が認められないが（図 8(b)）それ以外の㠜固物中には粒界 にそった鋭い亀裂が所々に認められた（図 8(a)）。

\section{7 熱 膨 脹}

凝固物中のガラスの分布を調べるため，ガラスを比較的多量に 含む $\mathrm{B}_{2} \mathrm{O}_{3}$ 含有組成の凝固物について，その底面から高さ 10

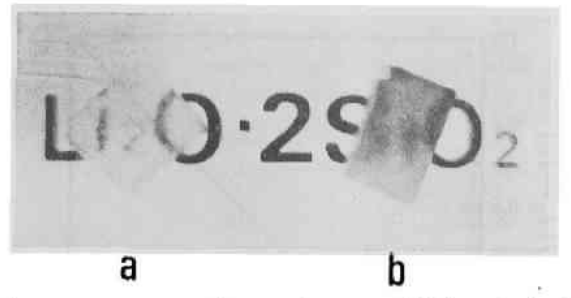

Fig.7 Transverse sections $3 \mathrm{~mm}$ thick of (a) L $2 \mathrm{~S}-$ $\mathrm{Na}$ and (b) L $2 \mathrm{~S}$ ingots
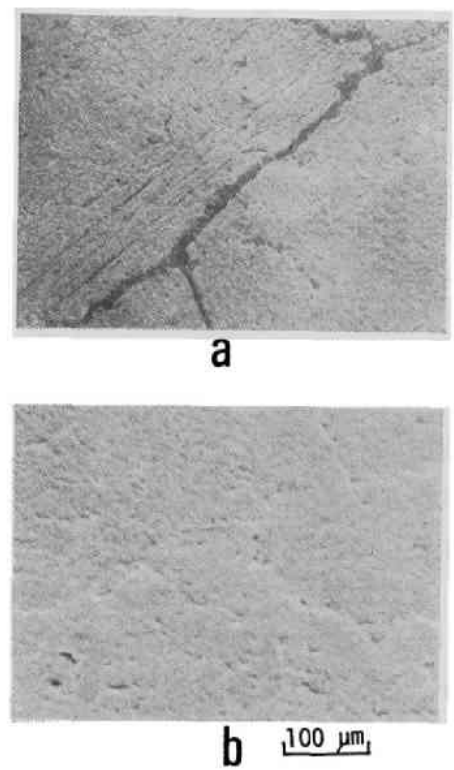

Fig. 8 Scanning electron micrographs of transverse sections of (a) L $2 \mathrm{~S}$ and (b) L $2 \mathrm{~S}-\mathrm{Na}$ ingots

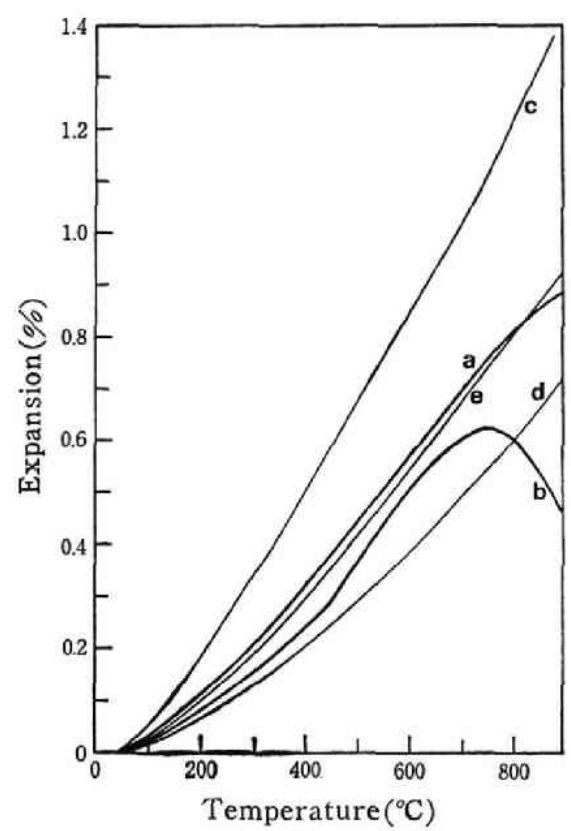

Fig.9 Thermal expansion of (a), (b) L 2 S-B ingot and (c), (d), (e) $\mathrm{Li}_{2} \mathrm{O} \cdot 2 \mathrm{SiO}_{2}$ single crystal

a : Along direction of crystal elongation, $b$ : Perpendicular to the direction of elongation, c : Along $a$-axis, $\mathrm{d}$ : Along $b$-axis, e : Along $c$-axis 
$25 \mathrm{~mm}$ の部分から結晶伸長方向，およびそれに直角な方向に長 い $5 \times 5 \times 15 \mathrm{~mm}$ の角型棒状試料を切り出し，それそれれの長い方 向についての熱膨脹を押棒式熱膨脹計により室温から $900^{\circ} \mathrm{C}$ の温 度域で測定した。結果を眓9に示す。図9 Kは比較のため既報で 報告した $\mathrm{Li}_{2} \mathrm{O} .2 \mathrm{SiO}_{2}$ 結晶の各結晶学的軸方向の熱膨脹2) る示し た。図 9 から, 上記凝固物は結晶伸長方向では $900^{\circ} \mathrm{C}$ ま温度が 上昇するにしたがいほぼ単調に膨脹するが，それに直角な方向で は $450^{\circ} \mathrm{C}$ 付近で膨非係数の增加を示し, さらに $800^{\circ} \mathrm{C}$ 以上では 押棒の加重により急激に軟化变形子ることがわかる。

\section{3 考察}

$\mathrm{Li}_{2} \mathrm{O} .2 \mathrm{SiO}_{2}$ 組成 $100 \mathrm{~mol}$ に対し $3 \mathrm{~mol}$ の種々の第 3 成分を 添加すると，凝固物中の結晶の配向性はほとんど变化しないが， 結晶の径は小さくなり，また凝固物の真気孔率は第 3 成分の種類 によりいちじるしく変化することは前に述べた。この第 3 成分添 加による結晶径および気孔率変化の原因について考察する。

第 3 成分を含さ融液から $\mathrm{Li}_{2} \mathrm{O} .2 \mathrm{SiO}_{2}$ 結晶が析出すると結晶中 K固溶し得ない第 3 成分は，結晶-融液界面付近の融液中に排出 され，そこに濃縮するので組成的過冷が生 は, セルラー状に成長しやすくなるき。結晶がセルラー状に成長 すると第 3 成分は，ならんで成長する柱状晶の間でとくに高濃度 となり， $\mathrm{Li}_{2} \mathrm{O} .2 \mathrm{SiO}_{2}$ 結晶がその伸長方向に直角な方向へ成長す ることを妨げ，結晶径の増大が抑えられる。第 3 成分を含む融液 から析出した柱状晶の径が第 3 成分を含まない場合より小さくな るのはこのためであろう。

凝固物の真気孔率が，第 3 成分を含まない場合には $3.4 \%$ であ

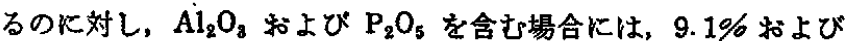
$7.6 \%$ と大きく，また $\mathrm{B}_{2} \mathrm{O}_{3} お よ ひ ~ \mathrm{Na}_{2} \mathrm{O}$ を含む場合には 1.7 および $1.1 \%$ と小さい原因はつぎのように説明できる。

第 3 成分を含まない凝固物が $3.4 \%$ の真気孔率を示す原因は, 既報2)で明らかにしたように，凝固物が凝固点から室温まで冷却 されるさい, $\mathrm{Li}_{2} \mathrm{O} \cdot 2 \mathrm{Si}_{2} \mathrm{O}$ 結晶の $a-, b$ - 軸方向の熱膨脹差によ り柱状晶間に熱応力が生し，そのため結晶粒界の一部に亀裂（図 8-a）が生成するためである。これに対し， $\mathrm{Al}_{2} \mathrm{O}_{3}$ または $\mathrm{P}_{2} \mathrm{O}_{5}$ を含む凝固物の場合には，図 6(e) および(g)から明らかなよら に, 上記の亀裂のほかに大きい円柱状気孔が多数観察される。こ の種の円柱状気孔は，別報》で明らかにしたよらに，融液中に溶 解した $\mathrm{H}_{2} \mathrm{O}$ ガスが凝固のさい, 結晶-融液界面付近に湱縮し, 気 泡となりそれが浮上する途中で成長する結晶に捕えられて形成さ れる。また結晶一融液界面付近における $\mathrm{H}_{2} \mathrm{O}$ ガスの濃 縮速度は, 凝固速度が同し場合，融液中の $\mathrm{H}_{2} \mathrm{O}$ ガスの拡散係数が小さいほど， またその溶解度が大きい注大゙ななる。したがって, $\mathrm{Al}_{2} \mathrm{O}_{3}$ ま たは $\mathrm{P}_{2} \mathrm{O}_{5}$ を含む凝固物の真気孔率が第 3 成分を含まない凝固物

6) B. Chalmers, "Principles of Solidification", John Wiley and Sons, Inc., New York (1964) p. 172.

7）有岡雅行，小久保 正，田代 仁，案劦，86，11号揭载予 定(1978).

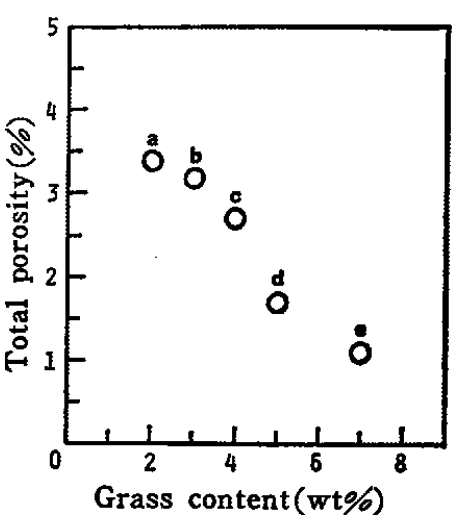

Fig. 10 Total porosity of ingots versus their glass content

$$
\begin{aligned}
& \text { a : L } 2 \text { S, b : L } 2 \text { S-Mg, c : L } 2 \text { S-Si, } \\
& \text { d : L } 2 \text { S-B, e : L } 2 \text { S-Na }
\end{aligned}
$$

のそれよりさらに大きくなった原因は，これらの第 3 成分を添加 することにより，蛝液中の $\mathrm{H}_{2} \mathrm{O}$ ガスの挔散係数が減少するか, あるいはその溶解度が堌大し，その結果，凝固の途中で結晶-融 液界面に接した融液中に $\mathrm{H}_{2} \mathrm{O}$ ガスの気泡が多量に発生し，それ が凝固物中に円柱状気孔として捕えられたためであると考えられ る。

一方， $\mathrm{B}_{2} \mathrm{O}_{3}$ または $\mathrm{Na}_{2} \mathrm{O}$ を添加した凝固物には，図 6(b) および（c），および図 8(b) から明らかなように，円柱状気孔 む，柱状晶間の龟裂も汪とんど喼められない。したがってこれら の凝固物の真䒽孔率が第 3 成分を含まない凝固物のそれより小さ くなった原因は，これらの第 3 成分添加により柱状晶の間の㤠 の発生が抑えられたためであると考えられる。 $\mathrm{Al}_{2} \mathrm{O}_{3}$ および $\mathrm{P}_{2} \mathrm{O}_{5}$ を添加した凝固物以外の凝固物について，それらの真気孔率をガ ラス含有量に対して図示したものが図 10 で,この図からガラス 含有量が増加するにしたがい真気孔率が減少することがかかる。

また図 9 によれば， $\mathrm{B}_{2} \mathrm{O}_{3}$ を添加した凝固物は結晶伸長方向に は $900^{\circ} \mathrm{C}$ まで単調に膨脹するだけであるが(a)，それに直角な方 向では $800^{\circ} \mathrm{C}$ 以上で押棒の重さにより軟化变形する(b)。このこ とから凝固物中のガラス相は柱状晶間に柱状晶と平行に存在する ことがわかる。さらに図 9 によれば同凝固物の結晶伸長方向に直 角な方向の熱脰脹には $450^{\circ} \mathrm{C}$ 付近にガラス転移によると考えられ る属曲点が認められるので，柱状晶間のガラスは $450^{\circ} \mathrm{C}$ 以上で粘 珄流動し得るものと考えられる。

以上の結果から, $\mathrm{Na}_{2} \mathrm{O}$ あるいは $\mathrm{B}_{2} \mathrm{O}_{3}$ を添加することにより 柱状晶間の亀裂の発生が㧕制される原因は，おるに柱状晶間に多 量のガラス相が形成され，このガラス相が流動することによっ て，凝固物が凝固点から室温まで冾却される間に生しる柱状晶間 の熱応力が，緩和されるためであると考えられる。

融液凝固実験にさいしては，京都大学化学研究所技官王城国造 氏の援助を受けた。本研究の一部は文部省科学研究費補助金（昭 和 51 年度試験研究（2）185176）の援助を受けて行なった。こ こに感謝します。 


\title{
Effect of Added Oxides on the Microstructure of Unidirectionally Solidified $\mathrm{Li}_{2} \mathrm{O} \cdot 2 \mathrm{SiO}_{2}$ Ceramics
}

\author{
Masayuki Arioka, Tadashi Koкubo and Megumi Tashiro \\ Institute for Chemical Research, Kyoto University; Uji-shi 611 Japan
}

Melts of the composition $100 \mathrm{Li}_{2} \cdot 200 \mathrm{SiO}_{2} \cdot 3 \mathrm{R}_{m} \mathrm{O}_{n}$ (mole ratio), where $\mathrm{R}_{m} \mathrm{O}_{n}\left(\mathrm{R}_{m} \mathrm{O}_{n}=\mathrm{B}_{2} \mathrm{O}_{3}\right.$, $\mathrm{Na}_{2} \mathrm{O}, \mathrm{MgO}, \mathrm{Al}_{2} \mathrm{O}_{3}, \mathrm{SiO}_{2}$ or $\mathrm{P}_{2} \mathrm{O}_{6}$ ) was an oxide component added, were unidirectionally solidified at a rate of $1.3 \mathrm{~mm} / \mathrm{hr}$ with a temperature gradient of $80^{\circ} \mathrm{C} / \mathrm{cm}$ in a clay crucible. A thin glass-ceramics layer- of $\mathrm{Li}_{2} \mathrm{O} \cdot 2 \mathrm{SiO}_{2}$ previously formed on the inner surface of the bottom of the crucible was used as the seed crystals. All the ingots made were composed mainly of columnar $\mathrm{Li}_{2} \mathrm{O} \cdot 2 \mathrm{SiO}_{2}$ crystals with their $c$-axes parallel to the direction of their elongation. The diameter of the columnar crystals was in the range $170 \sim 400 \mu \mathrm{m}$ for all the ingots containing $\mathrm{R}_{m} \mathrm{O}_{n}$ whereas it was $560 \mu \mathrm{m}$ for the ingot containing no $\mathrm{R}_{m} \mathrm{O}_{n}$. The total porosities of the ingots containing $\mathrm{Na}_{2} \mathrm{O}, \mathrm{B}_{2} \mathrm{O}_{3}, \mathrm{P}_{2} \mathrm{O}_{5}$ and $\mathrm{Al}_{2} \mathrm{O}_{3}$ were $1.1,1.7,7.6$ and $9.1 \%$, respectively, whereas the total porosity of the ingot containing no $\mathrm{R}_{m} \mathrm{O}_{n}$ was $3.4 \%$. The lower porosity of the ingots containing $\mathrm{Na}_{2} \mathrm{O}$ or $\mathrm{B}_{2} \mathrm{O}_{3}$ as compared with that of the $\mathrm{R}_{m} \mathrm{O}_{n^{-}}$ free ingot was attributed to the formation of a glassy matrix (5 7 wt\%) at the boundaries of the columnar crystals; Viscous flow formed in the presence of the glassy matrix probably relaxed thermal stresses induced in the ingots after solidification, thus supressing the formation of microcracks. 